\title{
Dampak Penyaluran Bantuan Sosial Tunai Pandemi Covid-19 (Studi Kasus di Kelurahan Sikumana - Kota Kupang)
}

\author{
Maria Prudensiana Leda Muga, Novi Theresia Kiak, Clarce Sarliana Maak \\ Universitas Nusa Cendana Kupang \\ Email: maria.muga@staf.undana.ac.id, ovi.kiak@staf.undana.ac.id, \\ clarce.maak@staf.undana.ac.id
}

\begin{tabular}{l}
\hline \hline Article Info \\
\hline Article history: \\
Published: June 28, 2021 \\
Page: 106 - 112 \\
\hline
\end{tabular}

\section{Keyword:}

Covid-19, Cash Social

Assistance, Sikumana

Villagecategory.

\begin{abstract}
Penelitian ini bertujuan untuk mengetahui pengelolaan Bantuan Sosial Tunai di Kelurahan Sikumana, selain itu untuk mengetahui lebih lanjut dampak dari bantuan sosial tunai (BST) kepada masyarakat terdampak Covid-19 di Kelurahan Sikumana. Metode penelitian yang digunakan yaitu metode kualitatif deskriptif, Hasil yang diperoleh dari penelitian ini menunjukkan bahwa pengelolaan bantuan covid -19 di Kelurahan sikumana belum optimal, dibutuhkan sosialisasi tentang manfaat bantuan tersebut, sehingga masyarakat mempunyai kesadaran akan pentingnya pelaporan data diri, sehingga tidak terjadi pendobelan data di kelurahan.
\end{abstract}

Kata Kunci : Covid 19, Bantuan sosial tunai, Sikumana

This study aims to determine the management of Cash Social Assistance in Sikumana Village, in addition to knowing more about the impact of cash social assistance (BST) on communities affected by Covid-19 in Sikumana Village. The research method used descriptive qualitative method. The results obtained from this study indicate that the management of COVID-19 assistance in the Sikumana Village is not optimal, socialization is needed about the benefits of the assistance, so that the community has awareness of the importance of selfdata reporting, so that data duplication does not occur. in the village.

Keywords : Covid-19, Cash Social Assistance, Sikumana Villagecategory.

\section{Copyright (C) 2021 OECONOMICUS Journal of Economics}

\section{Pendahuluan}

Pandemi Covid-19 yang sedang terjadi selama hampir dua tahun terakhir ini, sudah merupakan bencana global yang dampaknya mempengaruhi segala aspek kehidupan masyarakat, termasuk stabilitas ekonomi tiap negara. Berbagai upaya dilakukan Pemerintah Indonesian untuk

\section{Editorial Office:}

Prodi Ilmu Ekonomi Fakultas Ekonomi dan Bisnis Islam, UIN Sunan Ampel Surabaya

Jl. Ahmad Yani 117 Surabaya, Jawa Timur 60237, Indonesia.

Email: oje@uinsby.ac.id 
mengatasi pademi, pada semester 1 tahun 2020 pemerintah menerapkan beberapa upaya dan kebijakan untuk menangani pandemi Covid-19 yang menitik beratkan pada sektor kesehatan. Hal ini tertuang pada Keppres No.7 tahun 2020, tanggal 13 Maret 2020 tentang pembentukan gugus tugas percepatan penanganan Covid- 19. Selain itu pemerintah mengeluarkan beberapa kebijakan antara lain yaitu kampanye cuci tangan, penggunaan masker, jaga jarak secara masiv, pembatasan sosial berskala besar diberbagai wilayah, pelarangan mudik lebaran, persiapan laboratorium untuk testCovid-19 diberbagai tempat dan penetapam tatanan normal baru (Kompas, 2020).

Pada semester 2 tahun 2020 pemerintah membentuk komite penanganan Covid-19 dan pemulihan ekonomi melalui Perpres No.82 tahun 2020. Kebijakan fiskal dan moneter yang komprehensif diambil oleh pemerintah untuk pemulihan ekonomi nasional. Selain mengambil kebijakan fiskal dan moneter, dana APBN sebesar Rp 695,2 triliun dialokasikan untuk pemulihan ekonomi. Ada tiga kebijakan yang dilakukan pemerintah untuk pemulihan ekonomi nasional yaitu peningkatan konsumsi dalam negeri, peningkatan aktifitas dunia usaha serta menjaga stabilitas ekonomi dan ekspansi moneter. Kebijakan konsumsi dalam negeri dilakukan dengan meningkatkan daya beli masyarakat. Dana yang dialokasikan pemerintah untuk peningkatan daya beli masyarakat sebesar Rp 172,1 triliun. Dana tersebut disalurkan melalui Kementerian Sosial, dalam bentuk bantuan sosial. Bantuan sosial diharapakan bisa menstimulus perekonomian masyarakat mulai dari tingkat bawah. Beberapa program untuk menstimulus perekonomian antaranya bantuan tunai langsung, kartu prakerja, penurunan tarif listrik,stimulus UMKM micro dan lain-lain (Nainggolan, 2020).
Hasil penelitian Pramanik (2020) menunjukkan bantuan paket sembako dan bantuan langsung tunai memiliki pengaruh signifikan terhadap variabel kelangsungan hidup masyarkat di Padalarang. Namun, penyaluran BLT di Kecamatan Maesaan KabupatenMinahasa Selatan tidak sesuai dengan harapan ataupun tujuan. Karena masyarakat ekonomi mampu tetap menerima bantuan BLT (Wowiling, 2021), sehingga penelitian ini mencoba untuk mengidentifikasi dan mengevaluasi dampak penyaluran bantuan pandemiCovid-19 di Provinsi Nusa Tenggara Timur (NTT), Khususnya Kelurahan Sikumana- Kota Kupang.

Pemilihan Provinsi NTT, khususnya Kelurahan Sikuman- Kota Kupang sebagai objek penelitian, karena letak Kelurahan Sikumana berada di Kota Kupang yang pada saat pandemi Covid- 19 tergolong sebagai zona merah penyebaran Covid-19. Selain itu, kebijakan yang diambil oleh pemerintah untuk mengatasi pademi Covid 19 memberi dampak terhadap pertumbuhan ekonomi di Provinsi NTT. Hal dapat dilihat pada grafik 1.1 data pertumbuhan ekonomi NTT berdasarkan PDRB atas dasar harga konstan dari triwulan I sampai IV 2020.

Grafik 1.1

Data Pertumbuhan Ekonomi Nusa Tenggara Timur Triwulan I-IV Tahun 2019-2020

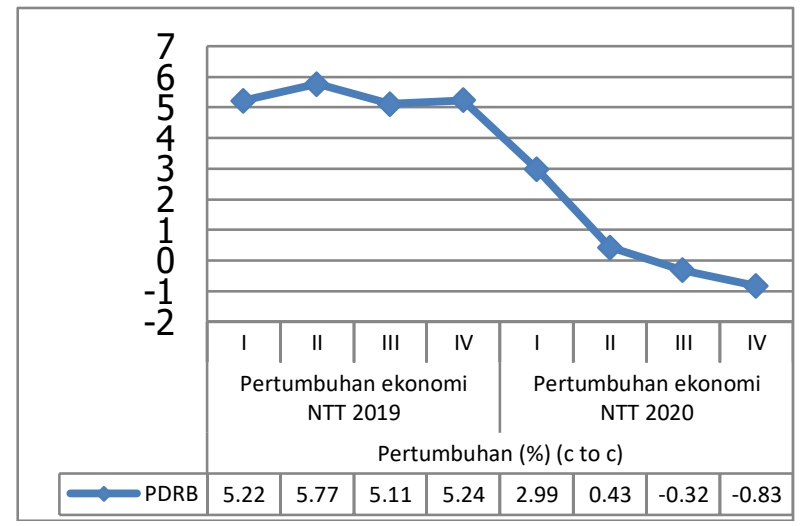

Sumber: Data BPS NTT,Diolah,2021

Grafik data di atas menunjukkan pertumbuhan ekonomi NTT pada triwulan I 2019 yang tumbuh sebesar 5,22\% (ctc) 
dbandingkan triwulan I 2020 turun sebesar 2,99\% (ctc),disebabkan oleh pandemiCovid-19. Pertumbuhan ekonomi NTT triwulan IV 2019 yang tumbuh $5,24 \%$ (etc) dibandingkan dengan triwulan IV 2020 yang kontraksi sebesar 0,83\% (ctc), disebabkan kebijakan yang di ambil pemerintah NTT yaitu pemberlakuan PSBB untuk menekan laju penyebaran Covid-19.

Berdasarkan latar belakang yang telah diuraikan diatas, maka dapat dirumuskan bahwa permalahan dalam penelitian ini yaitu: 1) Bagaimana pengelolaan Bantuan Sosial Tunai di kelurahan Sikumana? 2) Bagaimana dampak dari bantuan Sosial Tunai (BST) kepada Masyarakat terdampak Covid-19 di Kelurahan Sikumana?

Adapun maksud dari penelitian ini yaitu untuk mengetahui pengelolaan Bantuan Sosial Tunai di Kelurahan Sikumana, Kota Kupang. Selain itu, untuk mengetahui lebih lanjut dampak bantuan tersebut.

\section{Kajian Pustaka}

\section{Pandemi Covid 19 dan kebijakan}

Pandemi Covid-19 yang terjadi sejak tahun 2020 membawa risiko bagi kesehatan masyarakat dan telah merenggut banyak korban jiwa di berbagai belahan penjuru dunia,,termasuk Indonesia. Pandemi COVID-19 ini mengganggu aktivitas ekonomi dan membawa dampak yang besar bagi perekonomian global dunia, termasuk Indonesia. Akibatnya dari pademi COVID-19, pertumbuhan ekonomi global mengalami penurunan, bahkan menganggu aktivitas perekonomian Indonesia. Terganggunya aktivitas ekonomi Indonesia memberi tekanan kepada perubahan dalam postur Anggaran Pendapatan dan Belanja negara,khususnya disisi pembiayaan, sehingga diperlukan respon kebijakan keuangan negara dan fiskal untuk menghadapi risiko pandemic COVID-19
(Perpu No.1, 2020).

(UU) Nomor 2 Tahun 2020 tentang Kebijakan Keuangan Negara dan Stabilitas Sistem Keuangan untuk Penanganan Pandemi Covid-19 dimaksudkan untuk memberikan perlindungan bagi kehidupan masyarakat yang sangat nyata terancam dengan merebak dan menyebarnya Covid-19, baik dari aspek keselamatan jiwa karena ancaman kesehatan dan keselamatan, maupun kehidupan sosial dan perekonomian masyarakat. Seluruh kebijakan di dalam UU Nomor 2 Tahun 2020, terutama kebijakan di bidang keuangan negara yang telah diimplementasikan saat ini, telah didasarkan pada asesmen dan menggunakan data faktual dampak ancaman Covid-19 bagi masyarakat dan negara.

\section{Program Bantuan Sosial}

Menurut Kementerian Sosial (2011), bantuan sosial adalah bantuan yang sifatnya sementara yang diberikan kepada masyarakat miskin, dengan tujuan dapat meningkatkan kehidupannya secara wajar. Program bantuan sosial merupakan salah satu komponen program jaminan sosial yang menjadi bentuk realisasi tanggung jawab pemerintah pusat atau pemerintah daerah yang sangat peduli terhadap kondisi masyarakat miskin dan terlantar di tingkat bawah. Program ini merupakan implementasi Undang- Undang Dasar 1945 Pasal 34 ayat 1 yang menyatakan bahwa fakir miskin dan anak-anak terlantar dipelihara oleh negara. Selain itu pada Undang-Undang Dasar 1945 Pasal 34 ayat 2 menyebutkan bahwa Negara mengembangkan sistem jaminan sosial bagi seluruh rakyat dan memberdayakan masyarakat yang lemah dan tidak mampu sesuai dengan martabat kemanusiaan.

Dasar hukum pemberian bantuan sosial sembako dan bantuan sosial tunai adalah Peraturan Pemerintah Pengganti 
Undang-Undang Nomor 1 Tahun 2020 tentang kebijakan keuangan negara dan stabilitas sistem keuangan untuk penanganan pandemi corona virus disease 2019 (COVID-19) dan/ dalam rangka menghadapi ancaman yang membahayakan perekonomian nasional dan atau stabilitas sistem keuangan. Pelaksanaan jaring pengaman sesuai yang diamanatkan didalam Peraturan Pengganti Undang-Undang Nomor 1 Tahun 2020, dilaksanakan melalui Keputusan Menteri Sosial Nomor 54/HUK/2020 tanggal 16 April 2020 tentang pelaksanaan bantuan sosial sembako dan bantuan sosial tunai dalam penanganan dampak corona virus disease 2019 (COVID 19). Dalam Keputusan ini yang menjadi penangungjawab pelaksanaan bantuan sosial sembako adalah Direktorat Jenderal Perlindungan dan Jaminan Sosial dan penangungjawab bantuan sosial tunai adalah Direktorat Jenderal Penanganan Fakir Miskin.

Pemberian bantuan sosial sembako dilaksanakan di wilayah Pemda DKI Jakarta, Pemda Kabupaten Bogor,Pemda Kota Depok, Pemda Kota Tangerang, Pemda Kota Tangerang Selatan dan Pemda Bekasi. Pelaksanaan pemberian bantuan sosial tunai dilaksanakan diluar kelima wilayah tersebut. Berdasarkan Keputusan Menteri Sosial No.54/HUK/2020, data keluarga penerima bantuan social sembako merupakan data usalan dari wilayah Pemda DKI Jakarta, Pemda Kabupaten Bogor,Pemda Kota Depok, Pemda Kota Tangerang, Pemda Kota Tangerang Selatan dan Pemda Bekasi. Data usulan untul bantuan sosial tunai berasal dari pemerintah daerah kabupaten/kota dengan melampirkan surat pernyataan kebenaran data keluarga penerima manfaat yang diusulkan sebagai keluarga penerima penerima bantuan sosial tunai. Pelaksanaan bantuan sosial sembako dan bantuan sosial tunai dibebankan pada Anggaran Pendapatan dan Belanja Negara
Tahun 2020.

Pada tanggal 8 Juli 2020 Keputusan Menteri Sosial Nomor 54/HUK/2020 mengalami perubahaan menjadi Keputusan Menteri Sosial Nomor 86/ HUK/2020, sumber usulan data yang semula merupakan usulan data pemerintah daerah kabupaten/ kota menjadi:

1. Sumber usulan data untuk bantuan sosial sembako berasal dari Pemerintah daerah Khusus Ibu Kota Jakarta oleh Gubernur DKI Jakarta; Pemda Kabupaten Bogor oleh Bupati Bogor; Pemda Kota Depok oleh Wali kota Depok; Pemda Kota Tangerang oleh Wali kota Tangerang;Pemda Kota Tangerang Selatan oleh Wali Kota Tangerang Selatan dan sumber data lain yang didaftarkan Kementerian Sosial. Sumber data lain ini harus di daftarkan pada masingmasing unit kerja eselon I dan selanjutnya diajukan kepada Direktorat Jenderal Perlindungan dan Jaminan Sosial.

2. Sumber usulan data bantuan sosial tunai berasal dari data terpadau kesejahteraan social; pemerintah daerah kabupaten/kota dan sumber data lain. Sumber data lain harus disampaikan kepada Pusat Data dan Informasi Kesejahteraan Sosial untuk ditetapkan dalam data terpadu kesejahteraan sosial.

\section{Tujuan dari rencana pemberian program bantuan}

Menurut Pramanik, N. D. (2020), Tujuan pemberian Program Bantuan yaitu menjaga daya beli masyarakat pada saat pandemi Covid 19. Bantuan-bantuan tersebut akan didistribusikan ke seluruh wilayah Indonesia, dan menyasar kepada warga terdampak secara langsung maupun tak langsung. Menariknya, menyoal bantuan tunai BST dan BLT, Presiden Joko Widodo mengatakan pemerintah akan memberikan bantuan uang tunai sebesar Rp 600.000 per bulan. 
Pemerintah menetapkan sejumlah syarat bagi masyarakat yang ingin mendapatkan bantuan sosial tunai tersebut. Rincian pentingnya adalah:

1. Calon penerima adalah masyarakat yang masuk dalam pendataan RT/RW dan berada di desa.

2. Calon penerima adalah mereka yang kehilangan mata pencarian di tengah pandemi corona.

3. Calon penerima tidak terdaftar sebagai penerima bantuan sosial (bansos) lain dari pemerintah pusat. Ini berarti calon penerima BLT dari Dana Desa tidak menerima Program Keluarga Harapan (PKH), Kartu Sembako, Paket Sembako, Bantuan Pangan Non Tunai (BPNT) hingga Kartu Prakerja.

4. Jika calon penerima tidak mendapatkan bansos dari program lain, tetapi belum terdaftar oleh RT/RW, maka bisa langsung menginformasikannya ke aparat desa.

5. Jika calon penerima memenuhi syarat, tetapi tidak memiliki Nomor Induk Kependudukan (NIK) dan Kartu Penduduk (KTP), tetap bisa mendapat bantuan tanpa harus membuat KTP lebih dulu. Tapi, penerima harus berdomisili di desa tersebut dan menulis alamat lengkapnya. Jika penerima sudah terdaftar dan valid maka BLT akan diberikan melalui tunai dan non tunai. Non tunai diberikan melalui transfer ke rekening bank penerima dan tunai boleh menghubungi aparat desa, bank milik negara atau diambil langsung di kantor pos terdekat. Jika Anda termasuk dari warga terdampak covid dan sudah memenuhi syarat untuk menerima bantuan sosial tunai.

Cara mengklaim Bantuan:

a. Pastikan tidak terdaftar di program bantuan sosial pemerintah yang lain;

b. Cek apakah nama Anda sudah terdaftar ke penerima bantuan sosial tunai ke RT/RW setempat;

c. Jika belum, daftarkan diri dengan melampirkan fotokopi KTP untuk diberikan ke kepala desa untuk data Anda diserahkan kepada bank-bank milik negara yang dilibatkan pada program;

d. (Tungguinformasi selanjutnya mengenai pencairan dana ke rekening Anda (jika memilih sistem transfer).

\section{Metode Penelitian}

Dalam penelitian ini, penulis menggunakan pendekatan kualitatif. Pendekatan ini mencoba memotret suatu realitas sebagai hal yang bersifat holistik/utuh, kompleks, dinamis, penuh makna dan hubungannya bersifat interaktif/ reciprocal (Sugiyono, 2018). Metode yang digunakan adalah metode deskriptif dengan analisis data kualitatif dimana metode ini meneliti status sekelompok manusia, obyek, kondisi, ataupun suatu peristiwa pada masa sekarang dengan menggambarkan secara sistematis, faktual dan akurat menegenai fakta-fakta, serta hubungan antar fenomena yang diselidiki (Nazir, 2014). Penulis menggunakan teknik pengumpulan data yaitu wawancara, observasi, dan dokumentasi. Dalam penelitian ini, ada dua jenis data yang digunakan penulis yaitu data Primer dan data Sekunder. Sumber data primer dari penelitian ini adalah reponden penelitian yang dianggap mengetahui persis pengelolaan penyaluran bantuan Covid-19 di Kelurahan Sikumana. Dalam proses pemilihan sampel sebagai responden dalam penelitian ini menggunakan snowball sampling, sehingga responden yang menjadi informan kunci awal dalam penelitian ini adalah pihak pengelola di Kelurahan 
Sikumana (lurah, sekretaris dan pegawai kelurahan). Informan yang digunakan dalam penelitian ini juga diambil sesuai dengan kebutuhan penelitian. Penulis memilih informan yang sesuai kriteria penelitian, yaitu Pemerintah setempat dalam hal ini Kelurahan Sikumana di Kota Kupang dan masyarakat penerima bantuan Covid-19. Dalam penelitian ini instrumen yang digunakan adalah pedoman wawancara indepth interview dengan tape recorder, lembar observasi, dan lembar ceklist dokumentasi. Tahap terakhir adalah tahap analisis data yang terdiri dari tahap pengumpulan data, reduksi data, penyajian data, dan verifikasi data.

\section{Hasil dan Pembahasan}

Dalam bagian ini, penulis ingin membahas tentang proses penyaluran bantuan pandemi Covid-19 di Kelurahan Sikumana, Kota Kupang, Nusa Tenggara Timur.

\section{Karakteristik informan}

Wawancara mendalam dilakukan terhadap Pejabat Kelurahan dan Pegawai Kelurahan, informan ini dipilih karena mengetahui dan mengelola kebijakan dari Kelurahan terkait dengan alur dan penyaluran bantuan pandemi Covid-19 yang selama ini berjalan di Kulurahan Sikumana.Adapun wawancara dilakukan kepada Ketua RT selaku pengawas dan pembantu Kelurahan, serta kepada masyarakat selaku penerima manfaat dari penyaluran bantuan pandemi Covid-19.

Hambatan dalam penentuan karakteristik informan dalam mendukung penulisan ini didapati beberapa kendala, antara lain: a) Keterbatasan jumlah penerima manfaat yang direkomendasikan oleh Kelurahan mengingat sebagaian besar masyarakat di Kelurahan Sikumana bermata pencaharian petani dan wirausaha sehingga penulis kesulitan untuk mengatur waktu wawancara; b) Minimnya kesadaran masyarakat terhadap pentingnya administrasi kependudukan mengakibatkan terjadinya pendobelan data dan membutuhkan waktu untuk dilakukan verifikasi lanjutan; dan c) Keterbatasan waktu penelitian yang dilakukan penulis untuk dapat menggali lebih jauh terkait permasalahan dan pemecahan dalam penelitian.

\section{Aspek Operasional Pengelolaan Dana Covid-19 di Kelurahan Sikumana}

Pada tahap penyaluran bantuan pandemi Covid-19 kepada masyarakat di Kelurahan Sikumana menurut Lurah Sikumana sudah sesuai dengan Keputusan Menteri Sosial. Verifikasi datacalon penerima bantuan dilaksanakan di tingkat RT/RW masingmasing dan dilaporkan ke Pemerintah Kelurahan Sikumana. Dokumen yang menjadi syarat utama bagi penerima bantuan pandemi Covid-19 adalah KTP dan Kartu Keluarga yang berdomisili di Kelurahan Sikumana. Selain itu, calon penerima bantuan pandemi Covid-19 merupakan masyarakat yang kehilangan mata pencaharian saat pandemi Covid-19 dan yang tidak menerima bantuan sosial lainnya sepertiProgram Keluarga Harapan (PKH), Kartu Sembako, Paket Sembako, Bantuan Pangan Non Tunai (BPNT) dan Kartu Prakerja.

\section{Aspek Hukum dan Peraturan Pengelolaan Dana Covid-19 di Kelurahan Sikumana.}

Berdasarkan hasil penelitian tentang aspek hukum dan peraturan pengelolaan dana Covid-19, bahwa di Kelurahan Sikumana Peraturannya tertera jelas sesuai Keputusan Menteri Sosial Nomor 54/HUK/2020 tentang Pelaksanaan Bantuan Sosial Sembako dan Bantuan Sosial Tunai dalam Penanganan Dampak 
Corona Virus Disease 2019 (Covid-19). Data keluarga penerima manfaat bantuan sosial tunai diprioritaskan berdasal dari data terpadu kesejahteraan sosial dan dapat berasal dari usulan pemerintah daerah kabupaten/kota dengan melampirkan surat pernyataan tanggungjawab mutlak mengenai kebenaran data keluarga penerima bantuan sosial tunai. Sumber Dana Bantual Sosial Tunai (BST) berasal dari Anggaran Pendapatan dan Belanja Negara Tahun 2020.

\section{Aspek Ekonomi Pengelolaan Dana Covid-19 di Kelurahan Sikumana}

Berdasarkan hasil penelitian tentang aspek ekonomi melalui penyaluran dana Covid-19, masyarakat yang kehilangan mata pencaharian dapat diperhatikan. Pemulihan ekonomi masyarakat menjadi tujuan diterapkannya penyaluran dana Covid-19. Hasil wawancara terhadap beberapa masyarakat ditemukan bahwa penyaluran dana tersebut dipergunakan untuk modal usaha dan membantu kebutuhan sehari-hari.

\section{Hambatan dalam Pengelolaan Dana Covid-19 di Kelurahan Sikumana}

Berdasarkan penelitian ini, terdapat hambatan yang mempengaruhi pengelolaan dana covid-19, yaitu: a) Data yang dipergunakan adalah data terpadu kesejahteraan sosial yang masih perlu diverifikasi kembali. Kendala ini berdampak pada administrasi kependudukan, dimana akibat masyarakat yang belum memahami pentingnya melaporkan data diri yang dituagkan dalam KTP dan Kartu Keluarga sehingga menyulitkan pada saat verifikasi data; b) Akses sarana dan Prasarana yang kurang memadai untuk pelayanan mengakibatkan keterlambatan pelaksaaan pendataan ulang dan verifikasi yang berdampak dalam penyaluran bantuan terlambat; c) SDM dari penerima manfaat yang masih minim sehingga untuk mengelola dan mempergunakan dana bantuan tersebut tidak dikelola secara benar untuk memenuhi kebutuhan dan meningkatkan perekonomian masyarakat.

\section{Kesimpulan}

Berdasarkan hasil penelitian tentang dampak penyaluran bantuan Covid-19 di Kelurahan Sikumana, Kota Kupang, dapat disimpulkan bahwa pengelolaan bantuan Covid-19 dari Kelurahan Sikumana kepada Masyarakat belum optimal. Pelaksanaan penyaluran masih belum memberi pemahaman yang baik kepada masyarakat terdampak, dimana masyarakat hanya diberi bantuan tetapi belum diberi sosialisasi tentang manfaat bantuan tersebut. Masyarakat juga belum mempunyai kesadaran akan pentingnya pelaporan data diri sehingga masih terjadi pendobelan data dikelurahan.

\section{Saran}

Bagi Pemerintah Kota Kupang Khususnya di kelurahan Sikumana harusnya memberikan sosialisasi tentang manfaat bantuan sosial sebelum menyalurkannya kepada masyarakat, sehingga kedepannya masyarakat akan lebih mudah memahami dan menggunakan dengan bijak bantuan sosial tersebut. Ada beberapa hal yang dapat diagendakan untuk diteliti dimasa mendatang diantaranya, memperluas cakupan daerah penelitian secara lebih luas yaitu di tingkat kabupaten/ kota kupang. Selain itu, berdasarkan hasil wawancara ada respopnden yang mengungkapkan bahwa selama mereka menerima bantuan sosial belum mendapatkan sosialisasi tentang alur penggunaan bantuan sosial tersebut sehingga bantuan yang seringkali didapat hanya sebagai pemenuhan kebutuhan sehari-hari. Kedepannya penelitian ini akan menarik, jika diteliti lebih dalam 
tentang aspek dan pengaruh sosialisasi bantuan bencana kepada masyarakat terdampak bencana.

\section{Daftar Pustaka}

Kemensos. (2011). Pedoman Umum Penanggulangan Kemiskinan Perkotaan Tahun 2011. Jakarta: Pemerintah Indonesia

Kementerian Keuangan Republik Indonesia, 8 Oktober 2020,uu no 2 tahun 2020 Bukti Negara Hadir Berikan Perlindungan Terhadap Dampak Covid19, Diakses Pada Tanggal 03 Juni 2021. https://www.kemenkeu.go.id/publikasi/ berita/uu-no-2-tahun-2020-

buktinegara-hadir-berikan-

perlindungan-terhadap-dampak-covid$19 /$.

Keputusan Menteri Sosial Republik Indonesia, No 54/ HUK/ 2020. TENTANG PELAKSANAAN BANTUAN SOSIAL SEMBAKO DAN BANTUAN SOSIAL TUNAI DALAM PENANGANAN DAMPAK CORONA VIRUS DISEASE 2019 (COVID-19).

Keputusan Menteri Sosial Republik Indonesia, No 86/ HUK/ 2020. TENTANG PERUBAHAN ATAS KEPUTUSAN MENTERI SOSIAL NO. 54/HUK/2020 TENTANG PELAKSANAAN BANTUAN SOSIAL SEMBAKO DAN BANTUAN SOSIAL TUNAI DALAM PENANGANAN DAMPAK CORONA VIRUS DISEASE 2019 (COVID-19).

Nazir, Moh.(2014) Metode Penelitian, Ghalia Indonesia, Jakarta.

Peraturan Pemerintah Pengganti UndangUndang Republik Indonesia. No.1 Th 2020. TENTANG KEBIJAKAN KEUANGAN NEGARA DAN STABILITAS SISTEM KEUANGAN UNTUK PENANGANAN PANDEMI CORONA VIRUS DISEASE 2019
(COVID-19) DAN/ ATAU DALAM

RANGKA

MENGHADAPI

ANCAMAN

YANG

MEMBAHAYAKAN

PEREKONOMIAN NASIONAL DAN

IATAU STABILITAS SISTEM

KEUANGAN.

Pramanik, N. D. (2020). Dampak bantuan paket sembako dan bantuan langsung tunai terhadap kelangsungan hidup masyarakat padalarang pada masa pandemi covid 19. JURNAL EKONOMI, SOSIAL \& HUMANIORA, 1(12), 113-120.

Sugiyono (2018), Metode Penelitian Kuantitatif, Kualitatif dan $R \& D$, Alfa BetaBandung.

Wowiling. (2021) Peran pemerintah desa dalam penyaluran bantuan langsung tunai pada masyarakat di masa pandemic covid 19 di Kecamatan Maesaan Kabupaten Minahasa Selatan. JURNAL POLITICO UNSRAT. Vol.10.No.4.

\section{Webiste}

https://kompaspedia.kompas.id/baca/papara n-topik/kebijakan-pemerintahmenangani-covid-19-sepanjangsemester-ii-2020

https://ntt.bps.go.id/publication/2021/02/26/ 28a3d01a29a82489c3f95190/provinsinusa-tenggara-timur-dalam-angka2021.html 